\title{
Whole and crushed nutlets of chia (Salvia hispanica) from Mexico as a source of functional gums
}

\author{
Maira SEGURA-CAMPOS ${ }^{1}$, Zaidy ACOSTA-CHI ${ }^{1}$, Gabriel ROSADO-RUBIO ${ }^{1}$, \\ Luis CHEL-GUERRERO ${ }^{1}$, David BETANCUR-ANCONA ${ }^{1 *}$
}

\begin{abstract}
The objective of this study was to characterize the chemical and functional properties of Mexican chia (Salvia hispanica) gums extracted from defatted whole and crushed nutlets using the Soxhlet and SFE- $\mathrm{CO}_{2}$ methods. Chia gums have interesting chemical and functional properties for the food industry. The oil and gum yields were in the range of 1.98-16.42\% and 5.81-12.60\%, respectively. The defatting procedure did not affect significantly the oil and gum extraction; the nutlet type (whole or crushed) was the only parameter influencing the yield. The proximate composition and the protein and fiber contents of chia gum were evaluated. Low contents of protein and fiber and high NFE levels were found in whole nutlet gums. The functional properties of chia gum extracted from whole and crushed nutlets with the Soxhlet and SFE-CO methods showed the following ranges of water absorption capacity of 62.64 to $143.66 \mathrm{~g} / \mathrm{g}$, water adsorption capacity of 0.69 to $1.35 \mathrm{~g} / \mathrm{g}$, and water and oil holding capacity of 100 to $149.28 \mathrm{~g} / \mathrm{g}$ and 19.5 to $40.4 \mathrm{~g} / \mathrm{g}$, respectively. The rheological behavior exhibited by the gums was pseudoplastic or shear thinning. From a functional perspective, chia gum is an important food component due its emulsifier and stabilizer potentials.
\end{abstract}

Keywords: hydrocolloids; rheology; supercritical fluid extraction; fats and oils; functional properties.

\section{Introduction}

By the time of the Spanish conquest, Mesoamerican peoples had domesticated at least 20 botanical species with different uses. Among those, amaranth, beans, black chia, and corn stood out from a nutritional standpoint. The relevance of those crops in the Aztec's diet is documented in the historical Florentine Codex. In particular, chia was as important as corn or even more in some regions. In the 16th century, the Codex Mendoza indicated that 21 of the 38 Aztec provincial states offered chia as annual tribute (Alonso-Calderon et al., 2013).

Salvia is the largest genus of the mint family Lamiaceae and is represented by about 1000 species. Based on the most recent classification, this genus is part of the subfamily Nepetoideae, tribe Mentheae, subtribe Salviinae. Chia (Salvia hispanica L.) is an annual herbaceous plant belonging to this taxonomic hierarchy. The fruit of chia, as in other plants of the Lamiaceae family, is a schizocarp consisting of indehiscent locules that separate to form four fruitlets, referred to mericarps or nutlets. Commercially, each of these fruitlets is called 'seed', but actually, the (true) seed is contained within each fruitlet. Each of these nutlets has a stratified pericarp: cuticle, epicarp, mesocarp, a layer of bone cells, and endocarp; the latter is in contact with the true seed (Capitani et al., 2013). The chemical composition in chia seed has been found to have higher amounts of proteins (21.5\%), total lipids (21.69\%), and alpha-linolenic fatty acid (544.8 $\mathrm{mg} / \mathrm{g}$ of total lipids). In addition, chia seeds have showed an intermediate antioxidant capacity (Sargi et al., 2013).

The fiber content of the chia nutlets corresponds to a polysaccharide with a high molecular weight $\left(0.8-2 \times 10^{6}\right.$
Da) (Lin et al., 1994). In 1996, FAO described it as a potential source of polysaccharide gum because of its exceptional mucilaginous properties at low concentration in aqueous solutions. Lin et al. (1994) proposed a structure of the basic unit of the polysaccharide as a tetrasaccharide with 4-O-metil$\alpha$-D-glucoronopyranosyl residues occurring as branches of $\beta$-D-xylopyranosyl on the main chain. The monosaccharides $\beta$-D-xylose, $\alpha$-D-glucose, and 4-O-metil- $\alpha$-D-glucoronic acids were obtained by acid hydrolysis in the proportion $2: 1: 1$, respectively (Muñoz et al., 2012).

In general, hydrocolloids are widely used in different applications in the food industry due to their ability to retain water. They are also notable for their thickening and gelling properties, syneresis control, etc. Based on the aforementioned, the objective of the present study was to determine the chemical and functional properties of chia (Salvia hispanica) gum obtained from whole and crushed nutlets from Mexico.

\section{Materials and methods}

\subsection{Materials}

Reagents were of analytical grade and purchased from J.T. Baker (Phillipsburg, NJ, USA), Sigma (Sigma Chemical Co., St. Louis, MO, USA), Merck (Darmstadt, Germany) and Bio-Rad (Bio-Rad Laboratories, Inc. Hercules, CA, USA). Chia (S. hispanica, L.) nulets were obtained in Yucatan State, Mexico. Standard Association of Official Analytical Chemists (1997) procedures were used to determine nitrogen (method 954.01), 
fat (method 920.39), ash (method 925.09), crude fiber (method 962.09), and moisture (method 925.09) contents in the nutlets (Association of Official Analytical Chemists, 1997). Nitrogen $\left(\mathrm{N}_{2}\right)$ content was quantified with a Kjeltec Digestion System (Tecator, Höganäs, Skåne län, Sweden) using cupric sulfate and potassium sulfate as catalysts. Protein content was calculated as nitrogen $\times 6.25$. Fat content was obtained by $1 \mathrm{~h}$ hexane extraction. Ash content was calculated from sample weight after burning at $550{ }^{\circ} \mathrm{C}$ for $2 \mathrm{~h}$. Moisture content was measured based on sample weight loss after oven-drying at $110^{\circ} \mathrm{C}$ for $2 \mathrm{~h}$. Carbohydrate content was estimated as nitrogen-free extract (NFE) by difference from the sum of the protein, fat, ash, and crude fiber content. The nutlets were divided in two groups; one group was kept as whole nutlets and another group was crushed in a Cemotec.

\subsection{Chia (S. hispanica, L.) gum extraction}

Gum extraction included defatting, hydration, solubilization, filtration, dehydration and pulverization of the nutlets. Soxhlet (Association of Official Analytical Chemists, 1997) and supercritical fluid extraction (SFE) (Ixtaina et al., 2011) methods were used for the defatting of nutlets with hexane and $\mathrm{CO}_{2}$, respectively. A $250 \mathrm{~mL}$ Soxhlet apparatus, $69^{\circ} \mathrm{C}$ of temperature and $4 \mathrm{~h}$ of reflux time, was used for chia nutlet oil extraction with hexane. $40 \mathrm{~g}$ of nutlets were used, and the solvent was recovered using a rotary evaporator. A SFT-150 system (Supercritical Fluid Technologies Inc, Newark, DE, USA), at $80^{\circ} \mathrm{C}$ and 450 bars for 40 min of dynamic extraction with a $\mathrm{CO}_{2}$ flow rate of $1.8 \mathrm{~g} / \mathrm{min}$ was used for the SFE. The nutlets $(40 \mathrm{~g})$ were defatted using the SFT-150 extraction system. Considering the type of the nutlets (whole and crushed) and the defatting procedure as experimental factors, a $2 \times 2$ factorial experiment was designed for the oil extraction, giving a total of 4 treatments. Six replicates were performed for each treatment. Oil yield was used as the response variable and calculated with the equation: Oil yield $(\%)=$ [oil weight $/$ sample weight $] \times$ 100. After, considering the nutlets (whole and crushed) and the oil extraction method as independent variables, a $2 \times 2$ factorial experiment was designed for gum extraction, giving a total of 4 treatments. Three replicates were performed for each treatment, and gum yield was used as the response variable. Briefly, the defatted nutlets were suspended in distilled water at the 1:20 (w/v) ratio. The suspension was maintained under stirring at $25-30^{\circ} \mathrm{C}$ for $2 \mathrm{~h}$ for complete solubilization. The gum was vacuum filtered and dried by evaporation. Finally, the gum was freeze-dried at $-47^{\circ} \mathrm{C}$ and $13 \times 10^{-3}$ mbar (FreeZone 4.5, Labconco. Kansas City, Missouri, USA), pulverized, and stored until analysis. Gum yield was calculated as follows: Gum yield= [gum weight $/$ seed weight] $\times 100$.

\subsection{Chemical characterization of chia (S. hispanica, L.) gums}

Standard Association of Official Analytical Chemists (1997) procedures were used to determine nitrogen (method 954.01), fat (method 920.39), ash (method 925.09), crude fiber (method 962.09), and moisture (method 925.09) contents in the gums (Association of Official Analytical Chemists, 1997).

\subsection{Functional Properties of chia (S. hispanica, L.) gums}

\section{Water Absorption capacity (WAbC)}

These properties were determined according to AACC method 88-04 (American Association of Cereal Chemists, 1984). Approximate water absorption capacity was first determined by weighing out $2 \mathrm{~g}$ (d.b.) of sample, adding water until saturation (approx. $40 \mathrm{~mL}$ ), and centrifuging at $2000 \mathrm{~g}$ for 10 min using a Beckman GS-15R centrifuge. Excess water was discarded, and the residue was weighed. Approximate water absorption capacity was calculated by dividing the increase in sample weight (g) by the quantity of water needed to complete original sample weight ( $2 \mathrm{~g}$ d.b.) to $15 \mathrm{~g}$. Water absorption capacity $\left(\mathrm{WA}_{b} \mathrm{C}\right)$ was then determined by placing samples in four tubes, adding different quantities of water to bracket the measurement ( 1.5 and $0.5 \mathrm{~mL}$ water above original weight and 1.5 and $0.5 \mathrm{~mL}$ water below, agitating vigorously in a vortex for $2 \mathrm{~min}$, and centrifuging at $2000 \mathrm{~g}$ for $10 \mathrm{~min}$ using a Beckman GS-15R centrifuge. The supernatant was discarded, and the residue was weighed. Average water absorbed was calculated, and the $\mathrm{WA}_{\mathrm{b}} \mathrm{C}$ was calculated and expressed as $\mathrm{g}$ water absorbed per $g$ of sample.

\section{Water adsorption capacity (WAdC)}

This property was determined according to Chen et al. (1984). Briefly, $1 \mathrm{~g}$ (d.b.) of sample was placed in an equilibrium micro-environment at $98 \%$ relative humidity, generated by placing $20 \mathrm{~mL}$ of saturated potassium sulfate saline solution in tightly sealed glass flasks, which were then placed in desiccators at $25^{\circ} \mathrm{C}$. The sample was left in the micro-environment until reaching constant weight $(72 \mathrm{~h})$. Water adsorption capacity was expressed as $\mathrm{g}$ of water per $\mathrm{g}$ of sample.

\section{Water-holding capacity (WHC) and oil-holding capacity (OHC)}

Both capacities were determined following Chau et al. (1997). Briefly, $1 \mathrm{~g}$ (d.b.) of sample was weighed and then stirred into $10 \mathrm{~mL}$ of distilled water or corn oil (Mazola, CPI International) for one minute. These fibrous suspensions were then centrifuged at $2200 \mathrm{~g}$ for $30 \mathrm{~min}$, and the supernatant volume was measured. Water holding capacity was expressed as $g$ of water held per $g$ of sample, and oil-holding capacity was expressed as $\mathrm{g}$ of oil held per $\mathrm{g}$ of gum. Corn oil density was $0.92 \mathrm{~g} / \mathrm{mL}$.

\section{Viscosity}

Apparent viscosity was evaluated using an adaptation of the Li \& Chang method on a AR2000 rheometer (TA Instruments, New Castle, DE) using a cone and plate system $(40 \mathrm{~mm})$ and share rate range from 1 to $500 \mathrm{~s}^{-1}$ at $25^{\circ} \mathrm{C}$. The samples were dispersed in water to $0.5,1.0,1.5$ and $2.0(\mathrm{w} / \mathrm{v}, \mathrm{db})$. The results were expressed in Pax s and data fitted to the Ostwald-de Waele model to determine the consitency index $(\mathrm{k})$ and flow behavior index (n). 


\subsection{Statistical analysis}

All experiments were carried out in triplicates. Data obtained were subjected to analysis of variance (ANOVA). Differences between the means were determined using the Duncan multiple range test (Montgomery, 2004).

\section{Results and discussion}

\subsection{Chemical characterization of chia nutlets}

The proximate composition of the chia nutlets showed the following values of moisture, ash, fat, protein, fiber, and nitrogen free extract (NFE) of $6.75 \pm 0.14,4.05 \pm 0.34,32.88 \pm 4.44,22.44$ $\pm 0.12,33.52 \pm 2.39$, and $7.13 \pm 0.97$, respectively. Mexican chia nutlets proved to be an important nutritional source of fat, protein, fiber and NFE, and these results were similar to those found in other South America countries. Da Silva-Marineli et al. (2014) and Pizarro et al. (2013) evaluated Chilean and Argentina chia seeds and found moisture, ash, fat, protein and fiber values of 5.82-7.74, 4.07-4.58, 30.22-30-97, 25.32-20.01 and 37.50, and $31.51 \%$, respectively. In general, the values obtained for the proximate composition of the chia nutlets were in agreement with the composition reported in the literature, as follows: 9-23 g protein/100 g (Coates \& Ayerza, 1996), 25-35 g lipids/ $100 \mathrm{~g}$ (Álvarez-Chávez et al., 2008; Ixtaina et al., 2011), and 18-41 g fiber/100 g (Ayerza \& Coates, 2000; Bushway et al., 1981; ReyesCaudillo et al., 2008). Although chia is not commercially grown as a protein source, the protein content is higher than that of traditional crops such as wheat, corn, rice, and oats. The nutlet does not contain gluten, so celiac disease patients could ingest any food prepared using chia in specialized formulations. On the other hand, its fiber content is equivalent to $100 \%$ of the daily requirements for this nutrient for the adult population. According to Bushway et al. (1981) and Reyes-Caudillo et al. (2008) the defatted flour has $40 \%$ fiber, $5 \%$ of which is soluble and it is part of the mucilage. Mucilage contained in chia may hinder the complete enzyme digestion. Reyes-Caudillo et al. (2008) reported that the insoluble fraction is the predominant fraction as compared to the soluble fraction.

\subsection{Yields of Oil and gum extracted from whole and crushed nutlets with Soxhlet and SFE-CO2 methods}

Table 1 shows the extraction yields of oil and gum extracted from chia nutlets. The oil yields of chia nutlets were higher in crushed nutlets. This behavior could be due to higher contact of the crushed nutlets with the solvent employed. The results showed that the defatting procedure was not significant for the oil extraction and that only the nutlet factor (whole or crushed) had an effect on the yield (Figure 1a). The differences in oil yield observed for the crushed nutlets could be attributed to the interaction effect but not to the main factors such as type of the nutlets and defatting procedure, $\mathrm{p}>0.05$ ). On the other hand, the variance analysis showed that the nutlets (whole or crushed), the defatting procedure and the interaction between them had a significant effect on the gum yield $(\mathrm{p}<0.05)$.

The individual analysis of the type of the nutlets and the defatting procedure suggested that the variability in the gum yield was by effect of the type of nutlet to which the interaction effect may be attributed because the defatting procedure did not have a significant effect ( $p>0.05$ ) (Figure 1b). The results showed that crushed nutlets had higher gum yield possibly due to the lower fat content that facilitated the hydration and to the higher gum yield obtained from the crushed nutlet coating and the presence of other components such as starch or protein which could have been solubilized in the water. The gum yields were in agreement with those reported in the literature, 10.9\% (SeguraCampos et al., 2014) and 7\% (Muñoz et al., 2012).

\subsection{Chemical characterization of chia gum extracted from whole and crushed nutlets with Soxhlet and SFE-CO2 methods}

According to Capitani et al. (2013), when nutlets are in contact with water, the exocarp swells, the cuticle is broken by depleting their elasticity, and the cell components are spilled out as mucilage surrounding the entire fruit surface, but being attached to it with remarkable tenacity. In nutlets of Lamiaceae, the mucilage consists of epidermal cells that swell or disintegrate into thin spiral fibrillae when they come into contact with water.

Ryding (1992), who studied the presence or absence of myxocarpy (mucilage exudation) in most genera of Lamiaceae, established that this phenomenon has only been recorded in the subfamily Nepetoideae, and within the subfamily about $75 \%$ of the species are mucilaginous. Ryding (2001) used the term 'myxodiaspory' for the condition of having mucilaginous diaspores irrespective of whether they are seeds or fruits. This author reported that species with small nutlets are more often myxodiasporic than species with large nutlets, and also that annuals are more often myxodiasporic than perennials. Sales et al. (2010), studying S. Plebeia R. Br., reported that the reaction of nutlets varies depending perhaps upon the maturity and age of the samples.

The results of the proximate analysis of the chia gums extracted from whole and crushed nutlets with Soxhlet and SFE-CO methods are shown in Table 2. The fiber content of the chia gum extracted from whole nutlets with the Soxhlet and $\mathrm{SFE}-\mathrm{CO}_{2}$ methods and from crushed nutlets with the SFE- $\mathrm{CO}_{2}$

Table 1. Yield of oil and gum extracted from whole and crushed nutlets with Soxhlet and SFE-CO $\mathrm{CO}_{2}$ ethods.

\begin{tabular}{ccrr}
\hline Nutlet & Defatting procedure & Oil yield (\%) & Gum yield (\%) \\
\hline Whole & SFE-CO $C_{2}$ & $2.29 \pm 0.08^{\mathrm{a}}$ & $7.20 \pm 0.08^{\mathrm{b}}$ \\
Whole & Soxhlet & $1.98 \pm 0.11^{\mathrm{a}}$ & $5.81 \pm 0.05^{\mathrm{a}}$ \\
Crushed & SFE-CO & $11.61 \pm 0.50^{\mathrm{b}}$ & $12.19 \pm 0.03^{\mathrm{c}}$ \\
Crushed & Soxhlet & $16.42 \pm 0.34^{\mathrm{c}}$ & $12.60 \pm 0.15^{\mathrm{d}}$ \\
\hline
\end{tabular}

a-d Different letters in the same column indicate statistical difference $(\mathrm{p}<0.05)$. 

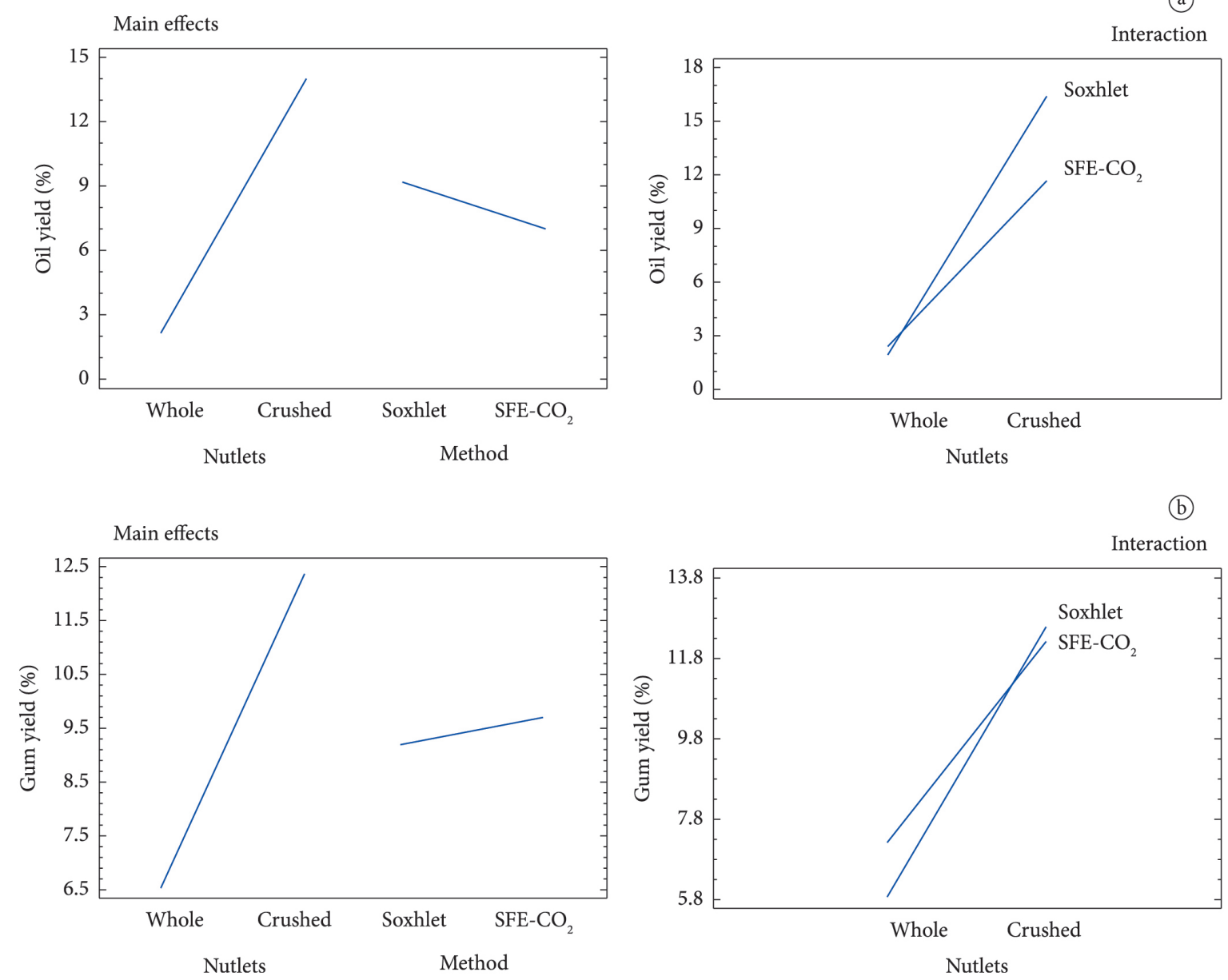

Figure 1. Main effects and interaction effects of oil (a) and gum (b) extracted from whole and crushed nutlets with the Soxhlet and SFE-CO methods.

Table 2. Proximate composition of chia gum extracted from whole and crushed nutlets with Soxhlet and SFE-CO methods.

\begin{tabular}{|c|c|c|c|c|}
\hline \multirow[b]{2}{*}{ Component } & \multicolumn{2}{|c|}{ Whole Nutlet Gum } & \multicolumn{2}{|c|}{ Crushed Nutlet Gum } \\
\hline & $\mathrm{SFE}-\mathrm{CO}_{2}$ & Soxhlet & SFE-CO & Soxhlet \\
\hline Moisture & $7.19^{\mathrm{a}}$ & $6.37^{\mathrm{b}}$ & $5.89^{\mathrm{b}}$ & $4.35^{\mathrm{c}}$ \\
\hline Ash & $10.67^{\mathrm{a}}$ & $9.58^{\mathrm{b}}$ & $8.82^{\mathrm{b}}$ & $9.09^{b}$ \\
\hline Fat & $3.12^{\mathrm{a}, \mathrm{c}}$ & $4.01^{\mathrm{b}}$ & $3.18^{\mathrm{a}}$ & $2.49^{c}$ \\
\hline Protein & $10.14^{\mathrm{a}}$ & $5.99^{\mathrm{b}}$ & $22.21^{\mathrm{c}}$ & $24.54^{\mathrm{d}}$ \\
\hline Fiber & $16.27^{\mathrm{a}}$ & $14.73^{\mathrm{a}}$ & $18.11^{\mathrm{a}}$ & $34.59^{\mathrm{b}}$ \\
\hline NFE & $59.80^{\mathrm{a}}$ & $65.70^{\mathrm{b}}$ & $47.70^{c}$ & $29.30^{\mathrm{d}}$ \\
\hline
\end{tabular}

${ }^{\mathrm{a}-\mathrm{d}}$ Different letters in the same row indicate statistical difference $\mathrm{p}<0.05$.

method was lower than that reported by Segura-Campos et al. (2014) in fatted (28.96\%) and partly defatted (18.99\%) chia gum. However, the fiber content of the chia gum extracted from crushed nutlets with the Soxhlet method was higher than that obtained by SFE- $\mathrm{CO}_{2}$ method with whole and crushed nutlets and by Segura-Campos et al. (2014) and Capitani et al. (2013) in gum extracted from Argentinian chia nutlets (13.5\%). The moisture content of all gums was lower to that reported by Segura-Campos et al. (2014) in fatted (9.32\%) and defatted (8.95\%) chia gum and to that reported in guar gum $(10.36 \%)$, xanthan gum (11.08\%), and Gleditsia triacanthos (14.08\%)
(Sciarini et al., 2005). With respect to the NFE content, all gums had higher values than those reported by Segura-Campos et al. (2014) in fatted (14.25\%) and defatted (28.41\%) chia gum and were similar to the value found in gum extracted from whole nutlets with Soxhlet method reported by Capitani et al. (2013) (63.7\%). The ash content was higher than that reported by Segura-Campos et al. (2014) in fatted (5.48\%) and defatted (8.28\%) chia gum and by Aber El Kader et al. (2002) in arabic gum (Acacia Senegal, 3.6\%), but it was similar to that reported by Sciarini et al. (2005) in xanthan gum (9.35\%). The protein content of all gums was higher than those in corn gum (5.1\%) 
and mesquite gum (5.8\%) (Bosquez-Molina et al., 2005). However, the protein contents registered here were lower than those reported by Segura-Campos et al. (2014) in fatted (25.07\%) and defatted (33.26\%) chia gum. López et al. (2006) stated that hydrocolloids rich in protein, such as gelatin, arabic gum, and mesquite are good stabilizers because they have sufficient hydrophobic groups to act as bonding points and hydrophilic groups that reduce surface tension in a liquid-liquid or liquidgas interface. On the other hand, Yadav et al. (2007) highlighted that the lipid content in gums may also play an important role in stabilization of oil-water emulsions. The fat content found in the present study was in the range from 2.49 to $4.01 \%$, and it was similar than that reported by Capitani et al. (2013) (3.1\%) but lower than that reported by Segura-Campos et al. (2014) in fatted $(26.24 \%)$ and partly defatted $(10.90 \%)$ chia gum. These findings suggest that chia gum could act as good emulsifiers and stabilizers in the food industry.

\subsection{Functional characterization of chia gum extracted from whole and crushed nutlets with the Soxhlet and SFE-CO2 methods}

Figure 2 shows the functional properties of chia gum extracted from whole and crushed nutlets with the Soxhlet and SFE- $\mathrm{CO}_{2}$ methods According to Zambrano et al. (2001), water absorption capacity is indicative of a structure's aptitude to spontaneously absorb water when placed in contact with a constantly moist surface or when immersed in water. The highest WAbC was observed in the gum extracted from whole nutlets with Soxhlet method (143.66g/g of sample), which was different $(\mathrm{p}<0.05)$ from the values obtained for the gum extracted from whole nutlets with the SFE- $\mathrm{CO}_{2}$ method (86.31g/g of sample) and for the gum extracted from crushed nutlets with the Soxhlet $(62.64 \mathrm{~g} / \mathrm{g}$ of sample) and SFE-CO
(75.98 g/g of sample) methods, respectively. All WAbC values found in the present study were higher than those reported by Segura-Campos et al. (2014) in fatted ( $44.08 \mathrm{~g} / \mathrm{g}$ of sample) and partly defatted ( $36.2 \mathrm{~g} / \mathrm{g}$ of sample) chia gum. A similar behavior was observed by Vázquez-Ovando et al. (2010) in a fiber-rich fraction of chia seeds ( $11.73 \mathrm{~g} / \mathrm{g}$ of sample).

According to Zambrano et al. (2001), water adsorption capacity is the ability of a structure to spontaneously adsorb water when exposed to an atmosphere of constant relative humidity. The highest WAdC was observed in the gum extracted from whole nutlets with the SFE- $\mathrm{CO}_{2}$ method $(1.35 \mathrm{~g} / \mathrm{g}$ of sample), which was different $(\mathrm{p}<0.05)$ than the values found for the gum extracted from whole nutlets with the Soxhlet method $(0.92 \mathrm{~g} / \mathrm{g}$ of sample) and for the gum extracted from crushed nutlets with the Soxhlet $\left(0.69 \mathrm{~g} / \mathrm{g}\right.$ of sample) and SFE- $\mathrm{CO}_{2}$ $(0.7 \mathrm{~g} / \mathrm{g}$ of sample) methods, respectively. The WAdC of chia gum extracted from whole nutlets with the $\mathrm{SFE}-\mathrm{CO}_{2}$ method was higher than that of fatted $(0.84 \mathrm{~g} / \mathrm{g}$ of sample) and defatted ( $0.27 \mathrm{~g} / \mathrm{g}$ of sample) chia gum reported by Segura-Campos et al. (2014) and a fiber-rich fraction of chia seeds ( $0.3 \mathrm{~g} / \mathrm{g}$ of sample) reported by Vázquez-Ovando et al. (2010).

The highest water holding capacity was observed in the gum extracted from whole nutlets with the SFE- $\mathrm{CO}_{2}$ method (149.28 g/g of sample). Both extraction methods employed here resulted in gums with higher WHC values than those found by Vázquez-Ovando et al. (2010), Baquero \& Bermúdez (1998) and Tamayo \& Bermudez (1998) in a fiber-rich fraction of chia seeds (15.41 g/g of fiber), passion fruit peel ( $8.7 \mathrm{~g} / \mathrm{g}$ of fiber), and orange waste (7.65-8.23 g/g of fiber), respectively. However, the results obtained here were similar to those reported by SeguraCampos et al. (2014) in fatted (103.2 $\mathrm{g} / \mathrm{g}$ of sample) and defatted (110.5g/g of sample) chia gum.

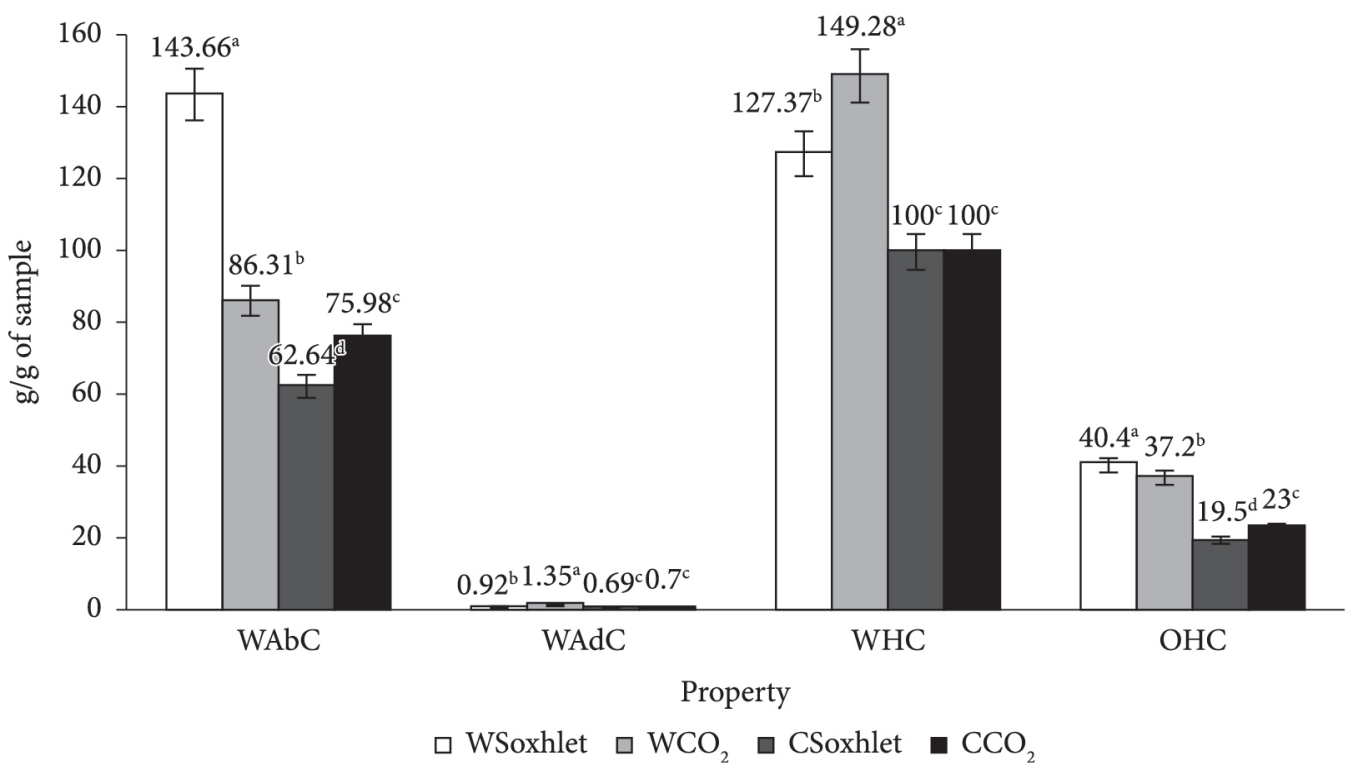

Figure 2. Functional properties of chia gum extracted from whole and crushed nutlets with the Soxhlet and SFE-CO methods. Water absorption

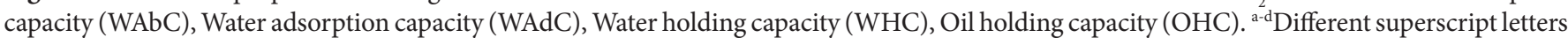
in the same property evaluated indicate statistical difference $(\mathrm{p}<0.05)$. 
$\mathrm{OHC}$ has been attributed to the physical entrapment of oil for molecules such as lipids and proteins. The highest $\mathrm{OHC}$ was observed in the gum extracted from whole nutlets with the Soxhlet method ( $40.4 \mathrm{~g} / \mathrm{g}$ of sample), which was different $(\mathrm{p}<0.05)$ from the values obtained for the gum extracted from whole nutlets with the SFE- $\mathrm{CO}_{2}$ method $(0.92 \mathrm{~g} / \mathrm{g}$ of sample) and for the gum extracted from crushed nutlets with the Soxhlet (19.5 g/g of sample) and SFE- $\mathrm{CO}_{2}(23 \mathrm{~g} / \mathrm{g}$ of sample) methods, respectively. With the exception of the crushed gum extracted with the Soxhlet defatting procedure, the other gum extraction methods used in present study had higher $\mathrm{OHC}$ values than those found in guar and xanthan gum (4-6 g oil/g fiber), arabic gum (8-9 g oil/g fiber) and fatted $(25.79 \mathrm{~g} / \mathrm{g}$ of sample) and defatted (11.67 g/g of sample) chia gum. Chia gum seems to possess an adequate fat absorption capacity, allowing it to play an important role in food processing since fat acts on flavor retainers and increases the mouth feel of foods.

Figure 3 shows the viscosity profiles of chia gum extracted from whole and crushed nutlets with the Soxhlet and SFE$\mathrm{CO}_{2}$ methods. The maximum viscosity values were observed in the gums extracted from whole nutlets and were directly proportional to the concentration. The higher viscosity of whole nutlets could be due to its higher WAbC and WHC compared with those found in the crushed nutlets. All gums exhibited a non-Newtonian behavior because viscosity was directly proportional to the shear rate. The results suggest that at high concentrations chia gums could be used to increase the
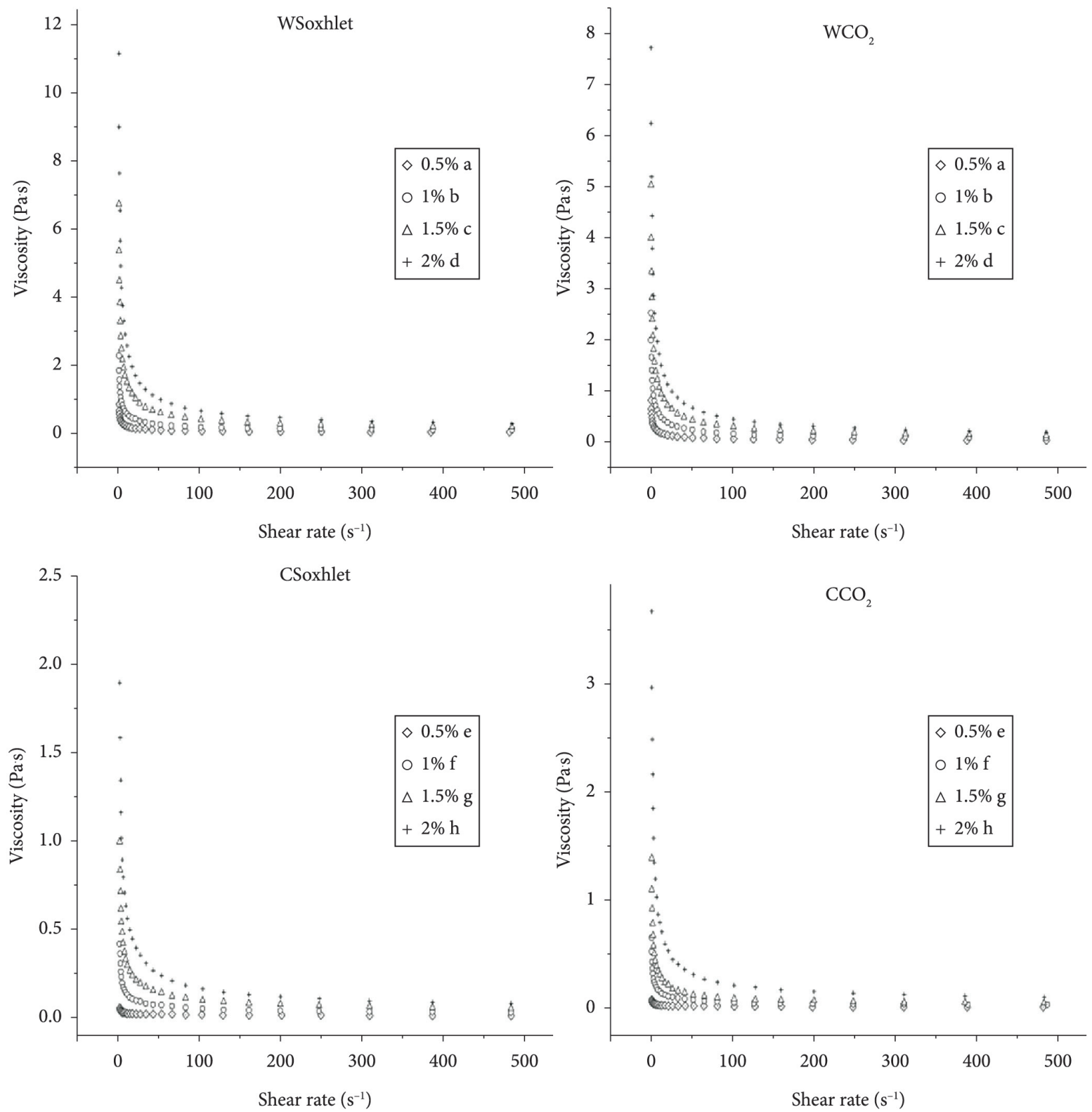

Figure 3. Viscosity profiles of chia gum extracted from whole and crushed nutlets with the Soxhlet and SFE-CO methods. 

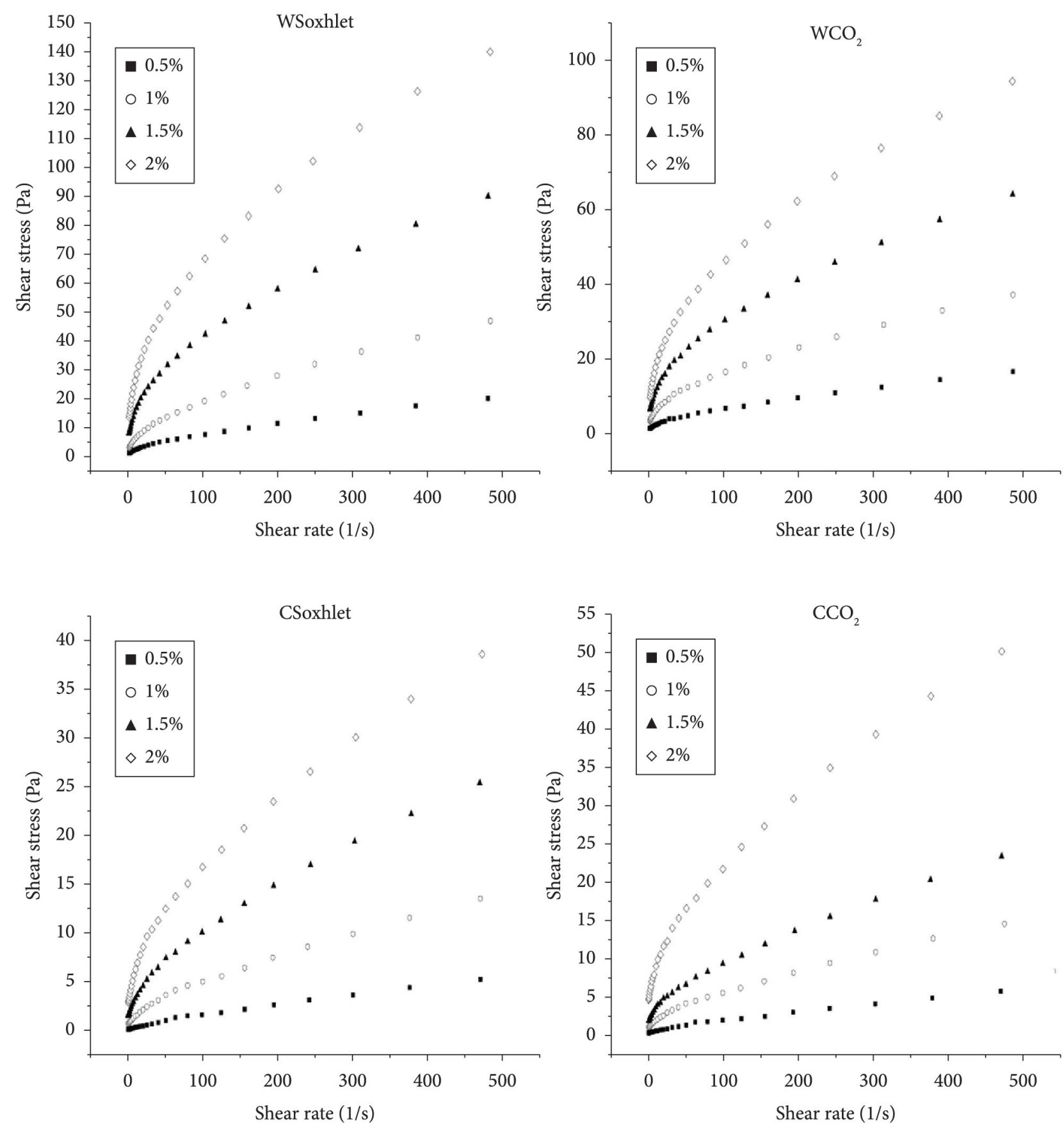

Figure 4. Shear stresss profiles of chia gum extracted from whole and crushed nutlets with the Soxhlet and SFE-CO methods.

viscosity with the characteristic of low viscosity at higher shear rate (reofluidificant behavior).

Figure 4 showed the shear stress profiles of chia gum extracted from whole and crushed nutlets with Soxhlet and SFE- $\mathrm{CO}_{2}$ methods. The results suggest a non-Newtonian behavior, in which shear stress was directly proportional to the concentration and inversely proportional to the shear rate. According to Table 3, Chia gum extracted from whole and crushed nutlets with the Soxhlet and SFE$\mathrm{CO}_{2}$ methods exhibited shear thinning or pseudoplastic rheological behavior since $\mathrm{n}<1$. The behavior index of the gums extracted from whole nutlets was similar to that of the gums extracted from crushed nutlets at high concentrations (1.5 and 2\%), showing the higher viscosity of the gums extracted from whole nutlets, including those extracted at low concentration levels. The behavior index of gums extracted from crushed nutlets at 0.5 and $1 \%$ suggested a Newtonian behavior because this parameter increased at low concentrations and viscosity levels. On the other hand, the consistency index was directly proportional to the concentration, suggesting higher viscosity levels, especially in the gums extracted from whole nutlets. 
Table 3. Consistency and behavior index of chia gum extracted from whole and crushed nutlets with Soxhlet and SFE-CO $\mathrm{C}_{2}$ ethods.

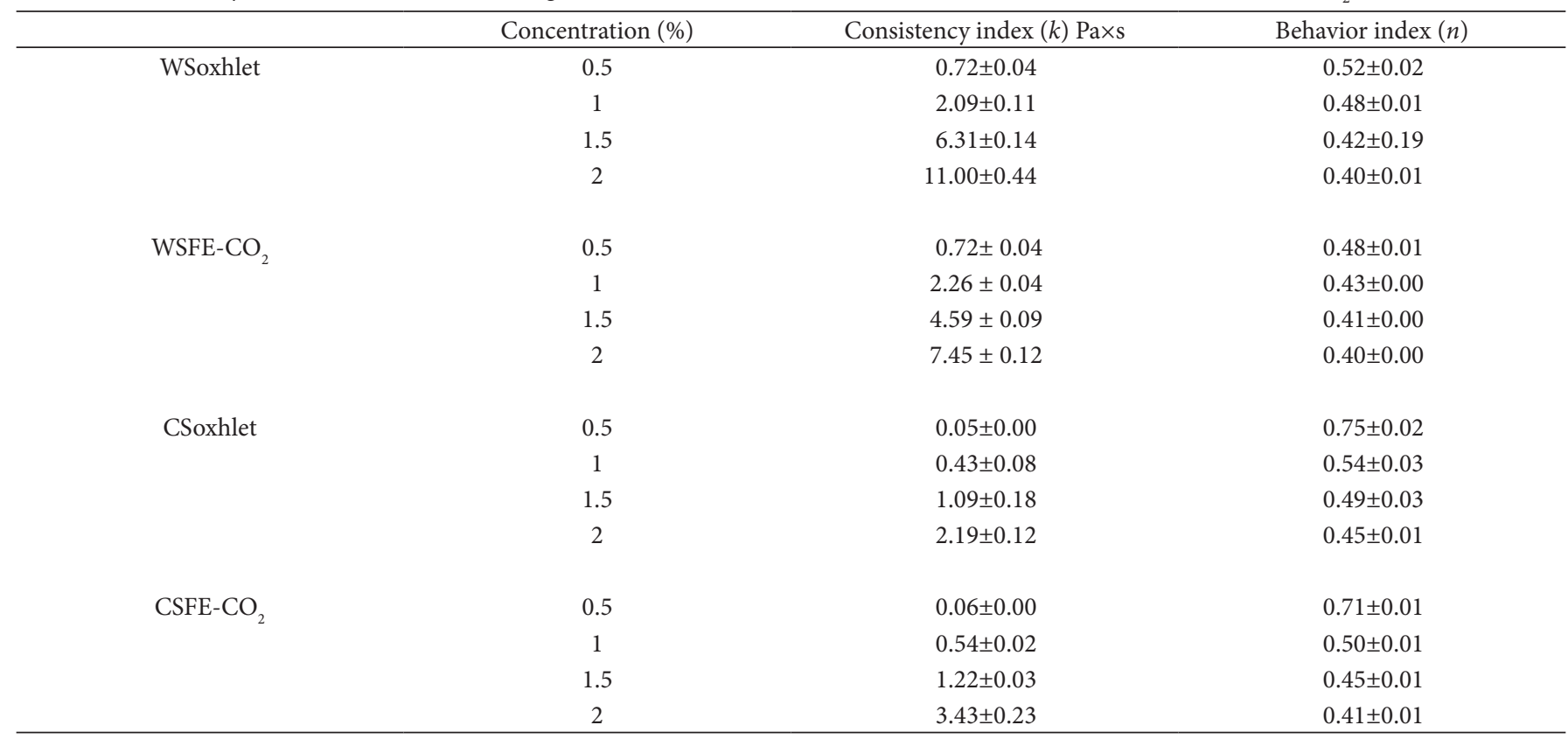

\section{Conclusions}

Chia gum extracted from whole and crushed nutlets from Mexico was characterized to determine their quality and potential as functional food additives. The results showed that defatting procedure did not influence the oil and gum extraction and that only the nutlet type (whole or crushed) had an effect on the yield. Lower protein and fiber contents and higher NFE levels were found in whole nutlet gums. The functional properties of chia gums found in the present study suggest their use as a food component due their emulsifier and stabilizer potentials.

\section{Acknowledgements}

This work was financially supported by Consejo Nacional de Ciencia y Tecnología-CONACYT- México.

\section{References}

Aber El Kader, D., Molina, E., León de Pinto, G., Negrón, G., \& Lachman, L. (2002). Caracterización analítica de cinco gomas Mimosaceae venezolanas y su posible aplicación industrial. Revista Facultad De Agronomía, 19, 230-239.

Alonso-Calderon, A., Chavez-Bravo, E., Rivera, A., Montalvo-Paquini, C., Arroyo-Tapia, R., Monterrosas-Santamaria, M., JiménezSalgado, T., \& Tapia-Hernández, A. (2013). Characterization of black chia seed (Salvia hispanica L.) and oil and quantification of $\beta$-sitosterol. International Research Journal of Biological Sciences., 2(1), 70-72.

Álvarez-Chávez, L. M., Valdivia-Lopez, M. A., Aburto-Juarez, M. L., \& Tecante, A. (2008). Chemical characterization of the lipid fraction of mexican chia seed (Salvia hispanica L.). International Journal of Food Properties, 11(3), 687-697. http:// dx.doi.org/10.1080/10942910701622656.
American Association of Cereal Chemists - AACC (1984). Approved Methods of the American Association of Cereal Chemists. St Paul: AACM.

Association of Official Analytical Chemists - AOAC (1997). Official Methods of Analysis. 20th ed. Washington: AOAC.

Ayerza, R., \& Coates, W. (2000). Dietary levels of chia: influence on yolk cholesterol, lipid content and fatty acid composition for two strains of hens. Poultry Science, 79(5), 724-739. http://dx.doi.org/10.1093/ ps/79.5.724. PMid:10824962

Baquero, C., \& Bermúdez, A. S. (1998). Los residuos vegetales de la industria del jugo de maracuyá como fuente de fibra dietaria. In: M. Lajolo \& E. Wenzel (Eds), Temas de Tecnologías de Alimentos (Vol. 2, pp. 207-214). México: Instituto Politécnico Nacional.

Bosquez-Molina, E., Guerrero-Legarreta, I., \& Vemon-Carter, E. J. (2005). Moisture barrier properties and morphology of mesquite gum-candelilla wax based edible emulsion coatings. Food Research International, 36 (9-10), 885-893.

Bushway, A. A., Belyea, P. R., \& Bushway, R. J. (1981). Chia seed as a source of oil, polysaccharide, and protein. Journal of Food Science, 46(5), 1349-1350. http://dx.doi.org/10.1111/j.1365-2621.1981. tb04171.x.

Capitani, M. I., Ixtaina, V. Y., Nolasco, S. M., \& Tomás, M. C. (2013). Microstructure, chemical composition and mucilage exudation of chia (Salvia hispanica L.) nutlets from Argentina. Journal of the Science of Food and Agriculture, 93(15), 3856-3862. http://dx.doi. org/10.1002/jsfa.6327. PMid:23900918

Chau, C., Cheung, K., \& Wong, Y. (1997). Functional properties of protein concentrates from three Chinese indigenous legume seeds. Journal of Agricultural and Food Chemistry, 45(7), 2500-2503. http:// dx.doi.org/10.1021/jf970047c.

Chen, J., Piva, M., \& Labuza, T. P. (1984). Evaluation of Water Binding Capacity (WBC) of Food Fiber Sources. Journal of Food Science, 49(1), 59-63. http://dx.doi.org/10.1111/j.1365-2621.1984.tb13668.x. 
Coates, W., \& Ayerza, R. (1996). Production potential of Chia in northwestern Argentina. Industrial Crops and Products, 5(3), 229233. http://dx.doi.org/10.1016/0926-6690(96)89454-4.

Da Silva Marineli, R., Aguiar Moraes, E., Alves Lenquiste, S., Teixeira Godoy, A., Nogueira Eberlin, M., \& Maróstica Jr., M. R. (2014). Chemical characterization and antioxidant potential of Chilean chia seeds and oil (Salvia hispanica L.). LWT - Food Science and Technology, 59(2), 1304-1310.

Ixtaina, V. Y., Martínez, M. L., Spotorno, V., Mateo, C. M., Maestri, D. M., Diehl, B. W. K., Nolasco, S. M., \& Tomás, M. C. (2011). Characterization of chia seed oils obtained by pressing and solvent extraction. Journal of Food Composition and Analysis, 24(2), 166174. http://dx.doi.org/10.1016/j.jfca.2010.08.006.

Li, G., \& Chang, K. (1997). Viscosity and gelling characteristics of sunflower pectin as affected by chemical and physical factors. Journal of Agricultural and Food Chemistry, 45(12), 4785-4789. http://dx.doi.org/10.1021/jf9708150.

Lin, K. Y., Daniel, J. R., \& Whistler, R. L. (1994). Structure of chia seed polysaccharide exudate. Carbohydrate Polymers, 23(1), 13-18. http:// dx.doi.org/10.1016/0144-8617(94)90085-X.

López, F. Y., Goycoolea, F., Valdez, M., \& Calderón, A. M. (2006). Goma de mezquite: una alternativa de uso industrial. Interciencia, 31(3), 183-189.

Montgomery, D. C. (2004). Diseño y Análisis de Experimentos (2nd ed.). México: Editorial Limusa Wiley.

Muñoz, L. A., Aguilera, J. M., Rodriguez-Turienzo, I., Cobos, A., \& Diaz, O. (2012). Characterization and microstructure of films made from mucilage of Salvia hispánica and whey protein concéntrate. Journal of Food Engineering, 111(3), 511-518. http://dx.doi. org/10.1016/j.jfoodeng.2012.02.031.

Pizarro, P. L., Almeida, E. L., Sammán, N. C., \& Chang, Y. K. (2013). Evaluation of whole chia (Salvia hispánica L.) flour and hydrogenated vegetable fat in pound cake. LWT - Food Science and Technology, 54(1), 73-79. http://dx.doi.org/10.1016/j.lwt.2013.04.017.

Reyes-Caudillo, E., Tecante, A., \& Valdivia-Lopez, M. A. (2008). Dietary fiber content and antioxidant activity of phenolic compounds present in Mexican chia (Salvia hispanica L.) seeds. Food Chemistry, 107(2), 656-663. http://dx.doi.org/10.1016/j.foodchem.2007.08.062.

Ryding, O. (1992). Pericarp structure and phylogeny within Lamiaceae subfamily Nepetoideae tribe Ocimeae. Nordic Journal of Botany,
12(3), 273-298. http://dx.doi.org/10.1111/j.1756-1051.1992. tb01304.x.

Ryding, O. (2001). Myxocarpy in the Nepetoideae (Lamiaceae) with notes on myxodiaspory in general. Systematics and Geography of Plants, 71(2), 503-504.

Sales, F., Hedge, I. C., \& Christie, F. (2010). Salvia plebeia R. BR.: taxonomy, phytogeography, autogamy andmyxospermy. Pakistan Journal of Botany, 42, 99-110.

Sargi, S. C., Silva, B. C., Santos, H. M. C., Montanher, P. F., Boeing, J. S., Santos-Júnior, O. O., Souza, N. E., \& Visentainer, J. V. (2013). Antioxidant capacity and chemical composition in seeds rich in omega-3: chia, flax, and perilla. Food Science and Technology (Campinas.), 33(3), 541-548. http://dx.doi.org/10.1590/S010120612013005000057.

Sciarini, L., Ribotta, P., Pérez, G., \& León, A. (2005). Extracción y caracterización del hidrocoloide de la semilla de Gleditsia triacanthos. Córdoba: Facultad de Ciencias Agropecuarias.

Segura-Campos, M. R., Ciau-Solis, N., Rosado-Rubio, G., ChelGuerrero, L., \& Betancur-Ancona, D. (2014). Chemical and functional properties of chia seed (Salvia hispánica L.) gum. International Journal of Food Science, 2014, 1-5. http://dx.doi. org/10.1155/2014/241053.

Tamayo, Y., \& Bermudez, A. (1998). Los residuos vegetales de la industria de jugos de naranja como fuente de fibra dietética. In: M. Lajolo \& E. Wenzel (Eds.), Temas de Tecnologías de Alimentos (Vol. 2, pp. 181-189). México: Instituto Politécnico Nacional.

Vázquez-Ovando, J. A., Rosado-Rubio, J. G., Chel-Guerreo, L. A., \& Betancur-Ancona, D. A. (2010). Procesamiento en seco de harina de chia (Salvia hispanica L.): caracterización química de fibra y proteína. CyTA - Journal of Food, 8(2), 117-127. http://dx.doi. org/10.1080/19476330903223580.

Yadav, M. P., Moreau, R. A., \& Hicks, K. B. (2007). Phenolic acids, lipids, and proteins associated with purified corn fiber arabinoxylans. Journal of Agricultural and Food Chemistry, 55(3), 943-947. http:// dx.doi.org/10.1021/jf0624493. PMid:17263497

Zambrano, M., Meléndez, R., \& Gallardo, Y. (2001). Propiedades Funcionales y Metodología para su Evaluación en Fibra Dietética. In: F. Lajolo, F. Saura-Calixto, E. Witting, \& E. Wenzel (Eds.), Fibra Dietética en Iberoamérica: Tecnología y Salud. Obtención, caracterización, efecto fisiológico y aplicación en alimentos (pp. 195209). Sao Paulo: Varela Editora e Livraría Ltda. 